\title{
Distribution of $\mathrm{GABA}_{A}$ and $\mathrm{GABA}_{B}$ Receptors in Mammalian Brain: Potential Targets for Drug Development
}

\author{
Anne B. Young and Dorothy Chu \\ Department of Neurology, University of Michigan, Ann Arbor, Michigan
}

\begin{abstract}
Young, A.B., and D. Chu : Distribution of $\mathrm{GABA}_{A}$ and $\mathrm{GABA}_{B}$ receptors in mammalian brain: potential targets for drug development. Drug Dev. Res. 21:161-167, 1990.

GABA is the major inhibitory neurotransmitter in mammalian brain. GABA receptors and the metabolism of GABA are significant targets for new centrally acting drugs to treat neurological and behavioral disorders. The simple neutral amino acid is likely to subserve a neurotransmitter role at $25-50 \%$ of all synapses in the central nervous system. GABA's actions are mediated by two different receptors, $G A B A_{A}$ and $G A B A_{B}$ receptors. $G A B A_{A}$ receptors are ligand-gated chloride channels that are sensitive to the convulsant alkaloid bicuculline and modulated by benzodiazepines and barbiturates. $\mathrm{GABA}_{\mathrm{B}}$ receptors affect calcium and potassium conductance through GTP binding proteins and are insensitive to bicuculline and sensitive to the agonist baclofen. Both receptors are widely distributed in cerebral cortex, hippocampus, basal ganglia, thalamus, cerebellum, and brainstem.
\end{abstract}

Key words: autoradiography, receptor localization, human, rat

\section{INTRODUCTION}

GABA (gamma-aminobutyric acid) is a neutral amino acid that subserves neurotransmitter functions at an estimated $25-50 \%$ of synapses in the mammalian central nervous system. GABA is present in brain in concentrations of $1-10 \mathrm{mM}$. The amino acid is synthesized from glutamate by the neuronal cytoplasmic enzyme glutamate decarboxylase and it is metabolized by mitochondrial enzymes to alpha-ketoglutarate that enters the Kreb's cycle. The synthetic and metabolic enzymes have been purified and antibodies raised against them. The enzymes have been localized in rat and human brain by using immunocytochemistry and the

Received final version July 17, 1990; accepted July 26, 1990.

Address reprint requests to Anne B. Young, M.D., Ph.D., Neuroscience Building, 1103 East Huron St., Ann Arbor, MI 48104-1687.

(C) 1990 Wiley-Liss, Inc. 
GABAergic pathways have been mapped by using this approach [Fagg and Foster, 1983; Ribak et al., 1979].

In the nerve terminal, GABA is stored in vesicles by a unique sodium-independent, ATP-dependent transport system that is selective for GABAergic neurons [Fykse and Fonnum, 1988; Hell et al., 1988]. This uptake system is biochemically and pharmacologically distinct from the neuronal and glial membrane high-affinity transport system and is driven by an electrochemical proton gradient [Wood and Sidhu, 1986; Debler and Lajtha, 1987; Krogsgaard-Larsen et al., 1987; Larsson et al., 1988]. GABA in vesicles and, perhaps, in the cytoplasm is released into the synaptic cleft upon depolarization of the terminal by a calciumdependent mechanism. After release, GABA diffuses across the synaptic cleft to interact with postsynaptic GABA receptors. GABA is inactivated by diffusion and by a high-affinity, sodium-dependent transport system into synaptic terminals and glial cells. The biochemical and pharmacological properties of this transport system have been studied in detail and will be reviewed in other articles in this volume.

GABA interacts with two receptor types, so-called $\mathrm{GABA}_{\mathrm{A}}$ and $\mathrm{GABA}_{\mathrm{B}}$ receptors [Stephenson, 1988; Bowery et al., 1988; Bormann, 1988]. GABA ${ }_{A}$ receptors are ligand-gated chloride channels that are modulated by benzodiazepines and barbiturates and inhibited by the convulsant alkaloid, bicuculline. $\mathrm{GABA}_{\mathrm{B}}$ receptors are insensitive to bicuculline and are sensitive to the agonist baclofen. In this chapter, the distribution of $G_{A B A}$ and $G_{A B A}$ receptors in normal rat and human brain will be reviewed.

\section{MATERIALS AND METHODS}

Male Sprague-Dawley rat brains and coronal sections of human brain from persons who died without neurological disease were stored in sealed containers until assay. Tissues were mounted onto cryotome pedestals with embedding matrix (Lipshaw) and were allowed to equilibrate in the cryostat at $-20^{\circ} \mathrm{C}$ [Chu et al., 1990, 1987b, 1987a]. Serial brain sections (20 $\mu \mathrm{m}$ thick, in horizontal or coronal plane) were cut on a Lipshaw cryotome at $-20^{\circ} \mathrm{C}$ to $-15^{\circ} \mathrm{C}$ and thaw mounted onto chrome-alum gelatin-coated slides. Prior to assay, sections were prewashed for $15 \mathrm{~min}$ in $50 \mathrm{mM}$ Tris- $\mathrm{HCl}$ buffer containing $2.5 \mathrm{mM} \mathrm{CaCl}$ (pH 7.40) at $4^{\circ} \mathrm{C}$. Slides were then removed from the buffer and dried under a stream of cool air.

$\left[{ }^{3} \mathrm{H}\right] \mathrm{GABA}$ was used to examine both $\mathrm{GABA}_{\mathrm{A}}$ and $\mathrm{GABA}_{\mathrm{B}}$ receptors. $\mathrm{GABA}_{\mathrm{B}}$ receptors were assayed by incubating sections for $45 \mathrm{~min}$ at $4^{\circ} \mathrm{C}$ with $\left[{ }^{3} \mathrm{H}\right] \mathrm{GABA}(20-25 \mathrm{nM})$ in 50 $\mathrm{mM}$ Tris- $\mathrm{HCl}$ buffer ( $\mathrm{pH} 7.4$ ), $2.5 \mathrm{mM} \mathrm{CaCl}_{2}$, and $10 \mu \mathrm{M}$ isoguvacine (a GABA $\mathrm{G}_{\mathrm{A}}$ agonist which specifically blocks $\left[{ }^{3} \mathrm{H}\right] \mathrm{GABA}$ binding to $\mathrm{GABA}_{\mathrm{A}}$ receptors). Nonspecific binding was determined in the presence of $100 \mu \mathrm{M}$ ( \pm )baclofen. $\mathrm{GABA}_{\mathrm{A}}$ receptors were assayed by incubating sections for $45 \mathrm{~min}$ at $4^{\circ} \mathrm{C}$ with $\left[{ }^{3} \mathrm{H}\right] \mathrm{GABA}(20-25 \mathrm{nM})$ in $50 \mathrm{mM}$ Tris-HCl buffer (pH 7.4), $2.5 \mathrm{mM} \mathrm{CaCl}_{2}$, and $100 \mu \mathrm{M}( \pm$ )baclofen (which blocks specifically binding to $\mathrm{GABA}_{\mathrm{B}}$ receptors). Nonspecific binding was determined in the presence of $100 \mu \mathrm{M}$ isoguvacine.

After incubation, slides were individually removed, subjected to three rapid squirts with buffer followed by one quick rinse with $2.5 \%$ glutaraldehyde in acetone and immediately blown dry with warm air. This rinse and dry procedure was completed within $15 \mathrm{sec}$. The slides were mounted in $\mathrm{x}$-ray cassettes and apposed to sheets of tritium-sensitive Ultrafilm ${ }^{3} \mathrm{H}$ (LKB) for 3 weeks at $4^{\circ} \mathrm{C}$. The films were developed in Kodak D19 for $3 \mathrm{~min}$ at $25^{\circ} \mathrm{C}$, fixed, and dried. Autoradiograms were analyzed by computer-assisted densitometry. Twenty to 25 readings from each region of interest on each section were averaged. Optical densities were quantified in pmol $\left[{ }^{3} \mathrm{H}\right] \mathrm{GABA}$ bound per $\mathrm{mg}$ protein by comparing film densities of brain with those generated by ${ }^{14} \mathrm{C}$-embedded plastic standards previously calibrated against brain paste standards containing known amounts of tritium and protein. 
TABLE 1. Comparison of $B_{\max }$ and $K_{D}$ Values for $G A B A_{A}$ and $G A B A_{B}$ Receptors in Various Regions of Rat and Human Brain*

\begin{tabular}{|c|c|c|}
\hline \multirow[b]{2}{*}{ Rat brain area } & \multicolumn{2}{|c|}{$\mathrm{B}_{\max }$ (pmol GABA bound/mg protein) } \\
\hline & $\mathrm{GABA}_{\mathrm{A}}$ & $\mathrm{GABA}_{\mathrm{B}}$ \\
\hline \multicolumn{3}{|l|}{ Cerebral cortex } \\
\hline Layers I-III & $4.02 \pm 0.26$ & $3.53 \pm 0.26$ \\
\hline Layer IV & $4.69 \pm 0.22$ & $1.87 \pm 0.24$ \\
\hline Neostriatum & $1.36 \pm 0.11$ & $0.91 \pm 0.12$ \\
\hline \multicolumn{3}{|l|}{ Dentate gyrus } \\
\hline Molecular layer & $3.97 \pm 0.13$ & $2.97 \pm 0.51$ \\
\hline \multicolumn{3}{|l|}{ Cerebellum } \\
\hline Molecular layer & $2.64 \pm 0.18$ & $3.58 \pm 0.49$ \\
\hline \multirow[t]{2}{*}{ Granular layer } & $9.30 \pm 0.38$ & $1.66 \pm 1.65$ \\
\hline & \multicolumn{2}{|c|}{$K_{D}(n M)$} \\
\hline \multicolumn{3}{|l|}{ Cerebral cortex } \\
\hline Layers I-III & $92 \pm 10$ & $341 \pm 41$ \\
\hline Layer IV & $100 \pm 19$ & $222 \pm 46$ \\
\hline Neostriatum & $70 \pm 14$ & $313 \pm 58$ \\
\hline \multicolumn{3}{|l|}{ Dentate gyrus } \\
\hline Molecular layer & $139 \pm 15$ & $462 \pm 54$ \\
\hline \multicolumn{3}{|l|}{ Cerebellum } \\
\hline Molecular layer & $164 \pm 26$ & $481 \pm 35$ \\
\hline \multirow[t]{2}{*}{ Granular layer } & $119 \pm 17$ & $458 \pm 193$ \\
\hline & \multicolumn{2}{|c|}{$\mathrm{B}_{\max }$ (pmol GABA bound/mg protein) } \\
\hline Human brain area & $\mathrm{GABA}_{\mathrm{A}}$ & $\mathrm{GABA}_{\mathrm{B}}$ \\
\hline \multicolumn{3}{|l|}{ Cerebral cortex } \\
\hline Layers II-III & $3.17 \pm 0.33$ & $1.26 \pm 0.08$ \\
\hline Layer V & $2.36 \pm 0.31$ & $1.08 \pm 0.12$ \\
\hline \multicolumn{3}{|l|}{ Hippocampus } \\
\hline Stratum moleculare dentate gyrus & $3.51 \pm 0.69$ & $1.09 \pm 0.15$ \\
\hline Stratum lacunosum-moleculare of CA1 & $2.33 \pm 0.21$ & $0.85 \pm 0.10$ \\
\hline Stratum pyramidale of $\mathrm{CA}$ & $3.50 \pm 0.42$ & $1.04 \pm 0.14$ \\
\hline \multirow[t]{2}{*}{ Subiculum } & $1.99 \pm 0.23$ & $0.55 \pm 0.17$ \\
\hline & \multicolumn{2}{|c|}{$\mathrm{K}_{\mathrm{D}}(\mathrm{nM})$} \\
\hline \multicolumn{3}{|l|}{ Cerebral cortex } \\
\hline Layers II-III & $121 \pm 30$ & $443 \pm 139$ \\
\hline Layer V & $136 \pm 33$ & $401 \pm 79$ \\
\hline \multicolumn{3}{|l|}{ Hippocampus } \\
\hline Stratum moleculare dentate gyrus & $234 \pm 84$ & $414 \pm 113$ \\
\hline Stratum lacunosum-moleculare of $\mathrm{CA} 1$ & $167 \pm 30$ & $318 \pm 74$ \\
\hline Stratum pyramidale of $\mathrm{CA}$ & $192 \pm 45$ & $355 \pm 99$ \\
\hline Subiculum & $191 \pm 46$ & $261 \pm 85$ \\
\hline
\end{tabular}

*Values represent mean $\pm S . E . M$. of four brains.

\section{RESULTS}

The affinity of $\mathrm{GABA}$ for rat and human $\mathrm{GABA}_{\mathrm{A}}$ receptors varied between 70 and 170 $\mathrm{nM}$ between regions whereas its affinity for $\mathrm{GABA}_{\mathrm{B}}$ receptors was $220-480 \mathrm{nM}$ and Hillnumbers for the two binding sites were very close to unity in all regions [Chu et al., 1990, 1987b, 1987a] (Table 1). Both receptor subtypes were widely distributed in mammalian brain but the relative densities of the two varied from region to region (Figs. 1,2). In olfactory bulb, $\mathrm{GABA}_{\mathrm{B}}$ binding was highest in the glomerular layers, whereas $\mathrm{GABA}_{\mathrm{A}}$ binding was most 

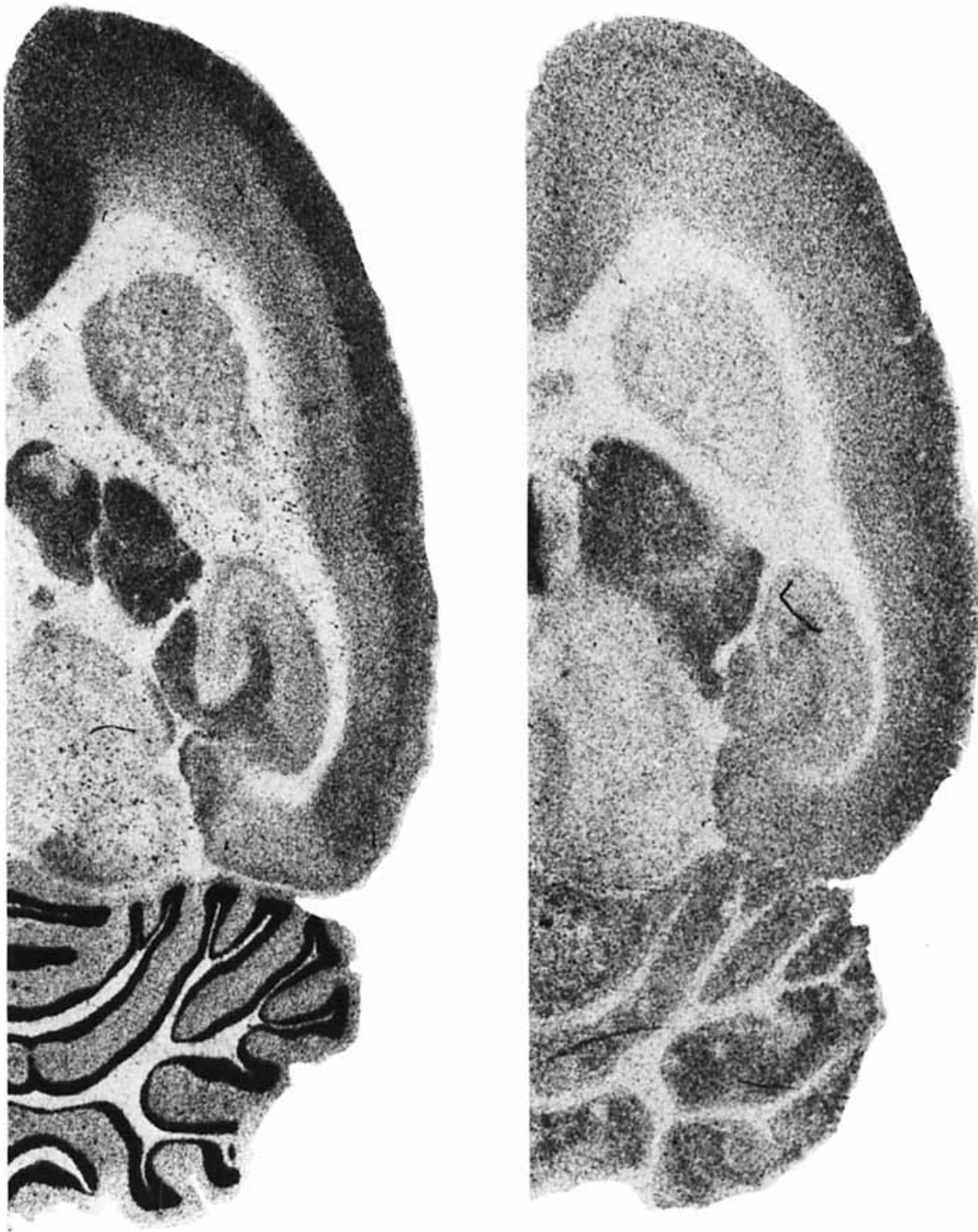

Fig. 1. $\mathrm{GABA}_{\mathrm{A}}$ (left) and $\mathrm{GABA}_{\mathrm{B}}$ (right) receptors in horizontal hemisections of rat brain. $\left[{ }^{3} \mathrm{H}\right] \mathrm{GABA}$ concentration was $24 \mathrm{nM}$ (magnification: $\times 7.25$ ).

dense in the external plexiform and inner granular layers. GABA receptor binding was dense for both subtypes of receptor in cerebral cortex although $\mathrm{GABA}_{\mathrm{A}}$ receptors were localized in distinct cortical layers (dense in layer I-IV) whereas $\mathrm{GABA}_{\mathrm{B}}$ binding was more diffusely distributed through cortex.

In most areas, $\mathrm{GABA}_{\mathrm{A}}$ receptors outnumbered $\mathrm{GABA}_{\mathrm{B}}$ receptors [Chu et al., 1990]. The exceptions were the medial habenula, the glomerular layer of the olfactory bulb, the superficial gray of the superior colliculus, the interpeduncular nucleus, the pontine nuclei, and the molecular layer of cerebellum where $\mathrm{GABA}_{\mathrm{B}}$ receptors were high and $\mathrm{GABA}_{\mathrm{A}}$ receptors were relatively low. 

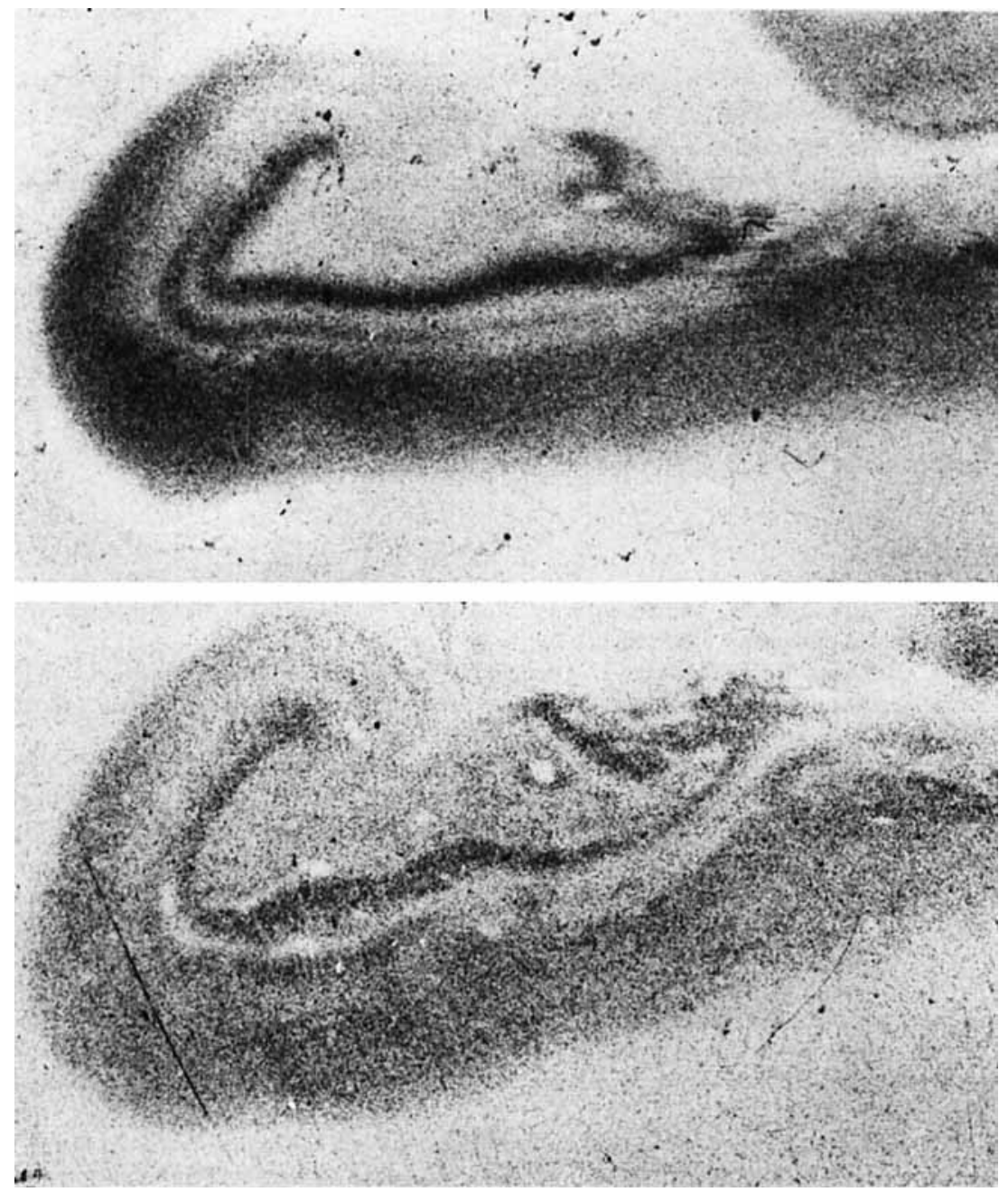

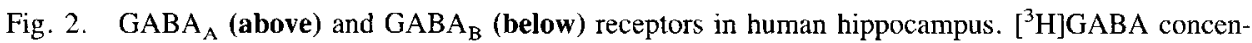
tration was $20 \mathrm{nM}$. The person died of nonneurological disease and was not on centrally active medications at the time of death (magnification: $\times 10$ ).

In human hippocampus, $\mathrm{GABA}_{\mathrm{A}}$ receptors outnumber $\mathrm{GABA}_{\mathrm{B}}$ receptors approximately three or four to one [Chu et al., 1987a]. The ratio of the two are fairly constant throughout the various hippocampal regions. The two receptor subtypes were most dense in stratum moleculare of dentate gyrus and stratum pyramidale of CA1 and less dense in stratum lacunosummoleculare of CA1 and subiculum.

\section{DISCUSSION}

$\mathrm{GABA}_{\mathrm{A}}$ and $\mathrm{GABA}_{\mathrm{B}}$ receptors were widely distributed in mammalian brain and are in high concentration in cortical, hippocampal, thalamic, basal ganglia, and cerebellar structures [Chu et al., 1990, 1987b,a; Wamsley et al., 1986; McCabe and Wamsley, 1986; Zezula et al., 
1988]. Drugs mediating actions at GABAergic synapses are likely to affect GABAergic function in multiple brain areas.

In recent years, the $\mathrm{GABA}_{\mathrm{A}}$ receptor has been purified and studied at the molecular level [Stephenson, 1988; Schofield et al., 1987; Barnard et al., 1987; Blair et al., 1988; Levitan et al., 1988]. Several subunits exist for the $\mathrm{GABA}_{\mathrm{A}}$ receptor and different isoforms of the various subunits have also been identified. The different subunits have unique pharmacological and electrophysiological properties. Antibodies against the receptor subunits have been used to map receptor localization [Houser et al., 1988; De Blas et al., 1988]. The various subunits are differentially distributed in brain [Wisden et al., 1988]. In the future, it may prove possible to design drugs that act on specific subpopulations of $\mathrm{GABA}_{\mathrm{A}}$ receptors.

\section{ACKNOWLEDGMENTS}

Supported by USPHS grants (no. 5) NS 19613 and NS 15655.

\section{REFERENCES}

Barnard, E.A., Darlison, M.G., and Seeburg, P.: Molecular biology of the GABAa receptor: the receptor/channel superfamily. TINS 10(12):502-508, 1987.

Blair, L.A.C., Levitan, E.S., Marshall, J., Dionne, V.E., and Barnard, E.A.: Single subunits of the GABAa receptor form ion channels with properties of the native receptor. Science 242:577-579, 1988.

Bormann, J.: Electrophysiology of GABAa and GABAb receptor subtypes. TINS 11(3):112-116, 1988.

Bowery, N.G., Hill, D.R., Hudson, A.L., and Price, G.W.: GABA-b receptors. In R.F. Squires (ed.): "GABA and Benzodiazepine Receptors. Volume 1." Boca Raton, Florida: CRC Press, Inc., 1988, pp. 107-121.

Chu, D.C.M., Penney, Jr., J.B., and Young, A.B.: Quantitative autoradiography of hippocampal $\mathrm{GABA}_{\mathrm{A}}$ and $\mathrm{GABA}_{\mathrm{B}}$ receptor changes in Alzheimer's disease. Neurosci. Lett. 82:246-252, $1987 \mathrm{a}$.

Chu, D.C.M., Penney, J.B., and Young, A.B. Cortical GABA $A_{B}$ and GABA $_{A}$ receptors in Alzheimer's disease: A quantitative autoradiographic study. Neurology 37:1454-1459, 1987b.

Chu, D.C.M., Albin, R.L., Young, A.B., and Penney, J.B.: Distribution and kinetics of GABA-B binding sites in rat central nervous system: a quantitative autoradiographic study. Neuroscience 34:341-357, 1990.

De Blas, A.L., Vitorica, J, and Friedrich, P. Localization of the GABAa receptor in the rat with a monoclonal antibody to the $57,000 \mathrm{Mr}$ peptide of the GABAa receptor/benzodiazepine receptor/ Cl-channel complex. J. Neurosci. 8(2):602-614, 1988.

Debler, E.A. and Lajtha, A.: High-affinity transport of gamma-aminobutyric acid, glycine, taurine, L-aspartic acid, and L-glutamic acid in synaptosomal (P2) tissue: a kinetic and substrate specificity analysis. J. Neurochem. 48:1851-1856, 1987.

Fagg, G.E. and Foster, A.C.: Amino acid neurotransmitters and their pathways in the mammalian central nervous system. Neuroscience 9:701-719, 1983.

Fykse, E.M. and Fonnum, F.: Uptake of gamma-aminobutyric acid by a synaptic vesicle fraction isolated from rat brain. J. Neurochem. 50:1237-1242, 1988.

Hell, J.W., Maycox, P.R., Stadler, H., and Jahn, R.: Uptake of GABA by rat brain synaptic vesicles isolated by a new procedure. EMBO J. 7(10):3023-3029, 1988.

Houser, C.R., Olsen, R.W., Richards, J.G., and Mohler, H. Immunohistochemical localization of benzodiazepine/GABAa receptors in the human hippocampal formation. J. Neurosci. 8(4):1370$1383,1988$.

Krogsgaard-Larsen, P., Falch, E., Larsson, O.M., and Schousboe, A.: GABA uptake inhibitors: relevance to antiepileptic drug research. Epilepsy Res. 1:77-93, 1987.

Larsson, O.M., Falch, E., Krogsgaard-Larsen, P., and Schousboe, A.: Kinetic characterization of inhibition of gamma-aminobutyric acid uptake into cultured neurons and astrocytes by 4,4-diphenyl3-butenyl derivatives of nipecotic acid and guvacine. J. Neurochem. 50:818-823, 1988.

Levitan, E.S., Schofield, P.R., Burt, D.R., Rhee, L.M., Wisden, W., Koehler, M., Fujita, N., Rod- 
riguez, H.F., Stephenson, F.A., Darlison, M.G., Barnard, E.A., and Seeburg, P.H.: Structural and functional basis for $\mathrm{GABA}_{\mathrm{A}}$ receptor heterogeneity. Nature 335:76-79, 1988 .

McCabe, R.Y. and Wamsley, J.K. II: Autoradiographic localization of subcomponents of the macromolecular GABA receptor complex. Life Sci. 39:1937-1945, 1986.

Ribak, C.E., Vaughn, J.E., and Roberts, E. The GABA neurons and their axon terminals in rat corpus striatum as demonstrated by GAD immunocytochemistry. J. Comp. Neurol. 187:261-284, 1979.

Schofield, P.R., Darlison, M.G., Fujita, N., Burt, D.R., Stephenson, F.A., Rodriguez, H., Rhee, L.M., Ramachandran, J., Reale, V., Glencorse, T.A., Seeburg, P.H., and Barnard, E. A.: Sequence and functional expression of the $\mathrm{GABA}_{\mathrm{A}}$ receptor shows a ligand-gated receptor super-family. Nature 328:221-228, 1987.

Stephenson, F.A.: Understanding the GABAa receptor: a chemically gated ion channel. Biochem. J. 249:21-32, 1988 .

Wamsley, J.K., Gehlert, D.R., and Olsen, R.W.: The benzodiazepine/barbiturate-sensitive convulsant/ GABA receptor/chloride ionophore complex: autoradiographic localization of individual components. In Olsen, R.W. and Venter, J.C.: "Benzodiazepine/GABA Receptors and Chloride Channels: Structural and Functional Properties." New York: Alan R. Liss, Inc. 1986, pp. 299-313.

Wisden, W., Morris, B.J., Darlison, M.G., Hunt, S.P., and Barnard, E.A.: Distinct GABA receptor alpha subunit mRNAs show differential patterns of expression in bovine brain. Neuron 1:937-947, 1988.

Wood, J.D. and Sidhu, H.S.: Uptake of gamma-aminobutyric acid by brain tissue preparations: a reevaluation. J. Neurochem. 46:739-744, 1986.

Zezula, J., Cortes, R., Probst, A., and Palacios, J.M.: Benzodiazepine receptor sites in the human brain: Autoradiographic mapping. Neuroscience 25:771-795, 1988. 